\title{
Law and the Spaces of Empire Introduction to the Special Issue
}

\author{
Nandini Chatterjee \\ University of Exeter \\ Lakshmi Subramanian \\ CSSSC, Kolkata
}

This special issue is a reflection on the role of law in structuring the real and imagined spaces of empire. Recently, there has been a surge of interest in imperial history, motivated by the perceived need to recover the specific political, economic, social and psychological routes traversed by different portions of the world in the journey towards a globalized modernity. ${ }^{1}$ Within this trend, there has been a particularly vibrant interest in tracing the role of law, especially during the age of empires, when it assumed a very special role in producing new regimes and social structures, the marks and effects of which postcolonial societies continue to bear. ${ }^{2}$ This markedly interdisciplinary interest in law and empire has demonstrated a high level of spatial awareness. Scholars from a number of disciplines have begun to think about empires as peculiarly structured spaces, bringing the insights and methodologies of historical geographers to work on non-traditional themes and material, one of these being legal pluralism, or the multiplicity of competing legal orders, all operational within the same jurisdiction. ${ }^{3}$ The diversity of approaches and conclusions in this growing and somewhat ill-defined area is obvious. Nonetheless, many seem to have arrived at the notion of empire as an inevitably multi-layered, porous and fractured space; a notion that does not discard the fact of colonial violence and the ideological aggression of imperialists, and indeed, builds upon them to displace a view of empires as territorially and ideologically stable and bounded units entailing predictable, if oppressive control of colonized populations by colonizers. ${ }^{4}$ In place of land-based empires with well-policed borders, clear laws and clean-cut bureaucracies, we now have borderlands and lumpy seascapes crisscrossed by corridors carved by trade, treaties and piracy. In place of the ideological surety of colonial "lawfare" and anti- 
colonial resistance, ${ }^{5}$ "jurisdictional jockeying" seems to be the forte of motley imperial legal actors. ${ }^{6}$ Such a vision has entailed, among other things, the awareness of alternative, non-metropolitan articulations of law, righteous order and justice, and the possibility that such articulations were convincing to many and effective in shaping the everyday empire. This collection of essays looks beyond pragmatic, situational "jockeying," and also ad-hoc rationalization or "jurispractice," towards recovering some of those alternative, non-dominant legal visions and the sources of their reasoning. In this way we seek to understand the legal spaces of empire from and through those alternative vantage points.

A number of historiographical trends have converged on this impromptu, and not always consciously shared, agenda of exploring the role of law in the structuration of imperial spaces. These include the obvious candidates of histoire croisée, ${ }^{7}$ transnational histories, ${ }^{8}$ histories of mobile populations and diasporas and of legal efforts to regulate their movements and rights, ${ }^{9}$ histories of borderlands, ${ }^{10}$ histories of penal settlements, ${ }^{11}$ but also histories of imperial diplomacy and treaty-making, ${ }^{12}$ new histories of settler colonies, ${ }^{13}$ explorations of trans-continental constitutions, ${ }^{14}$ and studies of political or legal philosophers who pondered upon the fact and justifications of empire. All of these works point to law's capacity for structuring human geographies, the scope that empire afforded to that power, and also to the contradictions that imperial rule generated.

Law, as we know, creates a very specific kind of space called jurisdiction - the area over which it has authority. This area is not necessarily territorial; it can be an arena of social interactions, such as commerce (mercantile law), war (military law), or religion (church law). Historians of political philosophy and jurisprudence have long been concerned with jurisdiction, as well as the source of its legitimacy-sovereignty. Since the Westphalian resolution in Europe, there has been a distinct contradiction between the claims of complete territorial sovereignty of national laws (defined against the claims of any universal empire or church), and the expansive ambitions of "secular" universal law (as natural law). Modern empires did not just complicate this territorial grid; they embodied its core contradiction. In its universalist mode, 
imperial law aspired to be global but not international since it denied the possibility of sovereignty to those not measuring up to supposedly universal standards that could only be derived from Europe. These modern empires simultaneously permitted the suspension of those alleged universal standards in connection to places beyond Europe, and with respect to the status, rights and governance of those who lived there. ${ }^{15}$ Tautologically, the universal standards themselves offered the principal needed for such differentiation - if Indigenous peoples of the Americas, Australia, or the African continent did not display what early modern European thinkers had decided were the 'natural' markers of human social behavior, they could be dispossessed, enslaved and exterminated. The rise of a new concept of treaty-based "law of nations" in the late eighteenth century added another layer of justification for the continued exclusion of most from this brave new world of law. Meanwhile, a few, mostly European settlers, entered the small club of the "powers of the world," considered adequately treaty-worthy by other members and capable of offering recognizable rights to their citizens. ${ }^{16}$ Racism as science offered a later, further and apparently less ambiguous principle (compared to geography, culture or politics) in this longue-durée effort at defining and justifying the "rule of colonial difference."17

Thus differentiated from their "Others," Europeans in the age of empires could continue to imagine law as absolute, universal and transcendent, even when it facilitated unrestrained violence, exclusion, and denial of humanity. Law, in such a mode, could only be a European gift to humanity, handed out in history through colonization. With the assumption that Europe was the unique crucible of lawfulness and civilization, the European heterosexual male could pose as the universal legal subject, entitled to stride across the "whole vacant earth" like a Colossus, responding to their ardent call "Come and till me, come and reap me!"18 Indeed, eminent legal scholars and philosophers such as Peter Fitzpatrick and Giorgio Agamben have pointed to this persistent "myth" of Europe's unique lawfulness on which modern law continues to rest, negating all other codes as myths, denying its own indeterminacy and duplicity, and relegating myriad others, within and outside Europe, to a perpetual "state of exception.", 
The ideological claims of imperial/colonial law have been judged by many scholars working on various parts of the British Empire (for example) to have been tremendously effective. They enabled and justified the creation of new techniques of governance aimed at utter transformation of existing social, political and economic structures of colonized societies, as well as the alteration of primary cultural categories; indeed, entire physical, political and mental geographies. But these older works also pointed towards the hybrid reality of imperial geographies, anticipating Lauren Benton's recent interventions. Thus, when the historical anthropologist Bernard Cohn emphasized the opposition between two normative systems within colonial Indian law, he was attempting to explain the failure of colonial law (and by extension modern Indian law) to gain either moral traction or efficient enforceability. ${ }^{20}$ His Africanist counterparts, writing much later, have pointed to slave-trading principalities on the west coast of Africa, noting how these regimes negotiated British abolitionism and the obligations imposed by treaties with Britain, without abandoning either their commitment to procuring coerced labour or concepts of power based on the ability to do so. ${ }^{21}$ Subsequent works on South Asian history have explored the reasons for and effects of (not necessarily peaceful) compromise and hybridity in colonial law. David Washbrook, for instance, suggested that the "military-fiscal" nature of the Company's government in India precluded any possibility of substantiation of the universalist, transformative claims of colonial law, rendering it perpetually "Janus-faced." 22 A similar story of pragmatic accommodation arising out of policy imperatives informed Radhika Singha's study of criminal justice in early colonial India, where Weberian claims of the state's exclusive right to legitimate violence were inevitably compromised through the accommodation of preexisting community identities, social and sexual hierarchies and privileges, rendering the universal legal subject elusive. ${ }^{23}$

Historians of political thought have of course powerfully argued that Europeans were capable of more complex and nuanced imaginations of global order, and of recognising the place of both non-Europeans as legal subjects and nonEuropeans sources of law and legitimacy within that order. Jennifer Pitts has pointed out that key British and French political and legal philosophers of the late eighteenth and early nineteenth century devised sophisticated rationales for incorporating distant 
places and unfamiliar people into a legal order that was also ethical and consistent; rather than only accommodating perceived difference on the basis of policy considerations. $^{24}$ In a more territorially and temporally located but also more pessimistic study, Robert Travers has pointed to the layering of empires in the political ideas of Alexander Dow, Warren Hastings, Philip Francis and others in eighteenth-century Bengal who attempted to explain the nature of the regime created by the East India Company's battles and intrigues as an inheritance from a Mughal constitutional order, albeit one that was largely imagined according to the interests of the particular East India Company faction that the specific writer represented. ${ }^{25}$

In this collection, we are curious but cautious about such claims of either sympathy or continuity, especially where conveniently invented traditions rendered colonial societies more governable, and bolstered rather than criticised the hierarchies of the colonial order. We are aware, for example, that based on his extensive study of the many collations of, and application of what purported to be the "native" or "customary" law of African societies, Martin Chanock has forcefully argued that such codification formalised racial difference, and their administration through segregated judicial systems built and sustained the racial hierarchies of colonial societies. ${ }^{26}$ Indeed, if we think of the kinds of social and legal geographies that the application of such allegedly indigenous legal systems created, we see not only spatial separation, but deprivation of economic, political and legal opportunities for Africans, obliged to reside in "reserves" or acquire special passes allowing them to travel for work to similarly segregated cities. On the other hand, colonised people themselves were not immune to the attractions of creative authenticity. In this connection, one can think equally of Chagga communities of Mount Kilimanjaro, innovative in their uses of property but claiming the legitimacy of customary law, ${ }^{27}$ while also being reminded of the spatial metaphor of "home and the world" used by the (inevitably male) Indian nationalist efforts in order to claim autonomy from the colonial state's interventions in key areas of social life (involving, among other things, control over women). ${ }^{28}$ This highlights the importance of gender in the creation and deployment of legally significant traditions, and reminds us of the frequently noted transformation of women into symbolically loaded territory for ethical and political competition rather than agents in their own right. ${ }^{29}$ 
Colonised people almost everywhere also learnt very rapidly how to deploy key categories of imperial/colonial ideology and governance against the colonisers themselves. This was not limited to European pirates in the Indian Ocean who flourished (sometimes lost, perhaps non-existent) pieces of paper to establish their status as lawful "privateers." By the early nineteenth century, several Indigenous nations in North America claimed to possess full-blown constitutions, and hence asserted their rightful place among the "powers of the world," with or without the benefit of cultural multi-dexterity possessed by occasional mixed-race leaders. ${ }^{30}$ Elsewhere, the "rule of law" has been shown to be a potent argument, regularly and sometimes successfully deployed by colonized people to question and subvert the coercive capacity of the colonial state. ${ }^{31}$

In encapsulating the kind of material presented by this set of essays, a concept that we find very useful is that of the "Middle Ground"-a spatial metaphor used by Richard White for describing a specific, historically and geographically located regime, created by motivated mutual misunderstandings between people in conflict, misunderstandings that were nevertheless productive of a new order in which at least functional communication could take place. $^{32}$ White was himself studying seventeenth-century Canada, and has declared bemusement at his conceptual framework for the Great Lakes being put to work for analysing contexts widely different from his own. While taking note of the dangers of taking explanatory frameworks too far from their empirical home, what attracts us to the notion of a "Middle Ground" is its in-built methodological need for, and hence the opportunity it offers, for examining carefully the different socio-cultural-political worlds from which operational concepts were derived for the ultimate hybrid product. For area specialists studying empire, this offers us the opportunity to study contact without losing context.

It is also important to highlight that we see interaction not only in ideational terms, but also in terms of governance, experience, and habitation. Historians of urbanism have offered us substantive material and contexts for exploring the idea of such negotiation. The possibility of a fluid space between the colonial state and the 
subject population was expanded by both Mattison Mines and Neil Brimnes who referred to the ways in which local society used European courts and participated in a fluid society of personal relationships that marked eighteenth-century urban society. ${ }^{33}$ The nature and ramifications of Anglo-Indian commercial relations and business partnerships in what Mines saw as a frontier space in colonial towns meant that there was a creative dialogue between judicial conventions and practices for a pragmatic resolution of disputes, although not necessarily any fundamental reconciliation of the normative systems in contact. Pointing to a less urbane and bleaker landscape, Clare Anderson's work on non-European, mainly Indian, convicts transported to penal settlements across the Indian Ocean, and her use of the biographical method based on non-traditional, extremely fragmentary sources offers insights into the way in which law, through punishment, substantiated colonial categories of differentiation, for example with the legal restriction of Indian convicts to within a certain distance from the equator, based on geo-biological theories. However, Anderson's biographical method transcends the narrative of regulation to point to the manner in which the subaltern subjects of her study travelled to and inhabited punitive sites, frequently managing to re-situate themselves in the social order of those places. ${ }^{34}$

"Law and the Spaces of Empire" engages with a number of key propositions arising out the existing literature, which are addressed by each of the essays in this collection, but in different ways, and with distinct, not necessarily reconcilable results. We are not equally convinced about the genuineness or effectiveness of the Burkean rhetoric of moral sympathy; not equally sure about the relative balance of conviction and instrumentality in colonised or marginal populations' use of metropolitan legal norms; and do not subscribe equally to a vision of shaky imperial regimes, porous boundaries, and European rulers dependent on the laws and customs of their indigenous subjects. However, we are all inspired by what we see as an emerging project of breaking down the idea of imperial sovereignty as an extension of metropolitan ideas. We are keen to reconstitute imperial sovereignty as an aggregation of plural legal realities and imaginations, without losing sight of the fact that this was a plurality shaped by unequal power, and indeed characterised by zones unbridled violence as much as the possibility of subaltern agency. We are concerned with policy imperatives and everyday governance as much as ideological statements 
and jurisprudence, and we are minded to retain the distinction between these, precisely so that we can explore the connections between them. Above all, however, we seek to highlight the alternative: the everyday practices, unsystematic resistance, and non-metropolitan voices, rationales and imaginations, and to work out the cultural and material worlds that shaped those other visions of the legal geographies of empire.

Given our focus, we are methodologically as well as intellectually charged with the need to discover not just contestation but its meaning in and through the messiness of moments of legal interaction, captured unsystematically in multi-sited colonial archives, in multiple genres of expression and in many languages. Articles in this collection therefore deploy a number of methodologies in order to trace that elusive quantity: the visions of those that did not win, or so it seemed at the time. In each case, the essays examine the place of law, the significance of location and meaning of empire for the protagonists of their stories, as well as the significance of those stories for historians studying empire today. Each investigates what kind of local apparatuses-social, intellectual, political or indeed clerical-deflected the regimes of dominance and difference, thereby producing parallel spaces that we can only attempt to imaginatively reclaim. Studying a wide geographical terrain comprising of territories and seas from the Bay of Bengal to the Cape Colony, including the maritime world of the Indian Ocean, and temporally extending between the late eighteenth to the early twentieth centuries, these articles and their findings are capable of collectively offering methodological and analytical answers to scholars working on related themes in other contexts.

Each essay in this collection addresses a specific context, temporally and geographically, within the range delineated above, and deploys a specific set of source material and interpretive methodology for asking how law structured the spaces of empire. Mitch Fraas' essay, "Making Claims: Indian Litigants and the expansion of the English legal world in the eighteenth century," is an exercise in trans-national history while also being a close study of the routine procedures of eighteenth-century English legal culture. Drawing on the concept of a "trans-national constitution," 
developed by scholars working on eighteenth-century Anglo-American negotiations of identity, rules of governance and political entitlements, Fraas extends the same story eastwards, producing the kind of multi-hemispheric imperial history that Peter Marshall has been recommending for some time now. ${ }^{35}$ Through a study of the legal conundrums raised by eighteenth-century Indian litigants who determinedly pursued their causes in a number of apex courts in England, and using a range of legal sources - briefs, judge's notebooks, expert legal opinion and the texts of judgmentsFraas arrives at a critically optimistic view of the capaciousness of identity and rights afforded by the emerging "imperial constitution," while noting the discomfitures and dissonances between different assessments of the place of India and Indians within the notion of British imperial subjecthood.

Nandini Chatterjee, in her essay "Hindu City and Just Empire: Banaras and India in Ali Ibrahim Khan's legal imagination," tells a comparable story from the opposite end, and shows how a Shi'a nobleman and a late Mughal bureaucrat recruited by the English East India Company was able to deploy familiar procedures of Islamic jurisprudence, combined with an equally well-known Mughal administrative rationality, in order to respond to the many demands on his position as judge-magistrate of Banaras, a north Indian city at the cusp of several competing empires. Using a combination of archival records and Persian manuscript sources, Chatterjee reveals that, when faced with the possibility of multiple laws and/or legal interpretations, Ali Ibrahim Khan strove to achieve justice not by referring to absolute religious and legal differences, but to the importance of locality. Here, reading Ali Ibrahim Khan's historical writing together with his legal commentary allows Chatterjee to uncover the principles which for him defined the legal implications of location; these turn out to be royal prerogative as well as shared social practice or custom.

Placed slightly later in time, Lakshmi Subramanian's essay on piracy in the northeastern Indian Ocean littoral, "Piracy and Legality in the Northward: Colonial articulations of law, custom and policy in the late-eighteenth and early-nineteenthcentury Bombay Presidency" reconstructs the highly commercialized economy of 
violence which the East Indian Company both participated in, and attempted to conquer. Through a close reading of archival records, she deconstructs the East India Company's legal discourse, which condemned myriad small coastal principalities and communities as "piratical," suppressing the material and political conditions that made maritime raiding the only viable lifestyle for many thus condemned. While not entirely convinced about the possibility of ethical sympathy under such conditions, she also recovers the more sensitive ethnography of certain officials of the East India Company and the Bombay Marine, and their recommendations for pragmatic compromise with such coastal actors. Finally, the article turns towards the selfunderstanding of such "pirates" themselves; and using testimony recorded during their trials, offers a view of resistant subalterns rather than adroit pirate-lawyers of the kind that Benton has written much about.

Neilesh Bose's "New Settler Colonial Histories at the Edges of Empire: 'Asiatics,' Settlers, and law in colonial South Africa" is the second self-consciously trans-national essay in the collection, and one that studies the legal experiences Indian, Chinese and Malay migrant workers in South Africa in order to unsettle the often implicitly held notion of "settlers" as European. Examining more than a century of discriminatory legislation, both in the colonies of South Africa and in India, the essay interrogates the legal category of "Asiatic," and highlights how such a geographical referent was a specific method of denying cultural particularity and highlighting absolute racial differences. The essay then proceeds to uncover the alternative categories of self-description used by such Indian, Chinese and Malay "settlers," and points to several different approaches taken, including assertion of local residence and subjectivity derived therefrom, but also clearly racialised assertions of being imperial subjects, aimed at self-distinction from native Africans, or "Kafirs.” In surveying alternative modes of self-description and self-assertion by these "other settlers," Bose recommends returning to the admittedly discriminatory category of "Asiatic," in order to recover the possibility of more inclusive histories, unrestricted by the national boundaries that continue to afflict studies of imperial law and resistance to it. 
Rajarshi Ghose, in his essay "Islamic Law and Imperial Space: British India as 'domain of Islam,' circa 1803-1870," points, like Chatterjee, to Islam as a source of alternative spatial and legal imagination, while engaging with a different period of time and a different set of protagonists in colonial northern India and Bengal. Rather than Shi'a administrators, we now have eminent Sunni religious scholars whose arguments about Islamic law and its political implications are articulated not in the specific-resolution-seeking context of legal trials but the expansive ethical-political space opened up by print (especially the Urdu press), associations and public debates. Tracing how across three spiritual/intellectual generations, Hanafi juriconsults, deploying familiar principles and argumentative techniques came to argue that the British empire in India was a domain of peace rather than war, Ghose reveals the powerful alternative claims of political legitimacy that arose from this apparently quiescent formulation.

And finally, Stephanie Jones' essay "Maritime Space as Law and Light: Retrieving William Clark Russell's An Ocean Free-Lance (1882)" returns attention to those European pirates whose negotiation of empire and law played a central role in Lauren Benton's explorations of legal pluralism. This inter-disciplinary essay critically highlights the distinctively English intertwining of legal and literary aesthetics in the age of empires; and points to multiple values expressed through the character of the unruly ocean-goer, sometimes privateer, sometimes pirate. Jones astutely points out that the continued romanticization of the pirate has long lent itself to implicit (and in some cases, explicit) valorisation of empire and justification of its violence. But the essay also points to the implicit ethical criticism of empire expressed by such maritime novels, in which the pirate is not only a wily negotiator of imperial laws, but sometimes also a defiant opponent, and at others an anxious seeker of an ethical space beyond law and beyond racial and national hierarchies. Returning attention to the question of sympathy and its possibility, Jones demonstrates that Clark Russell's novels reveal awareness of a crowded ocean, peopled with many "salty subalterns," whether or not he proves capable of imagining an adequate place of justice for all of them. 
Together, these essays make a significant intervention in the existing historiography on law and space in the context of empire. Without being overtly theoretical, they offer critical qualifications to the idea of an expansive European imperial sovereignty, and express constructive dissatisfaction with the notion of pragmatic negotiation of legal regimes by the marginal and the colonized. Instead, together they propose a number of ways in which historical protagonists, European and well as non-European, imagined different coherent versions of empire and law, and reveal the multiple sources of sovereignty that such imaginations and enunciations rested upon. Such a perspective enables us to treat the idea of legal posturing more critically, and suggest that there may be more to be learnt about the practices and understandings of entitlements, obligations, subjectivity and transgression in the age of empires. We envisage further work on the legal spaces of empire, among other things through investigations into the visible coding of space, for instance through maps and other material artefacts of representation; examination of the physical structuration of the courtrooms and their performative aspects; and studies of documentary regimes, pertaining both to routine governance and adjudication, as well as liminal situations such as immigration checkpoints and battlezones. In all this we hope to find area-specialists bringing their linguistic and archival skills to bear upon the broader questions of how empires shaped the world, to reveal what people other than European imperialists had to say about the process.

For correspondence: n.chatterjee@exeter.ac.uk; nilgiri98@gmail.com. We would like to thank the Arts and Humanities Research Council (AHRC) UK, the Indian Council of Historical Research (ICHR), and the Centre for Studies in Social Systems (CSSSC), Kolkata for funding and hosting the three-day workshop in December 2012 that led to this collection of essays. We would like to thank all members and associates of the "Subjects of Law" research network, staff and associates of CSSSC, Kolkata who have contributed in many ways over several months, helping us finesse and improve the individual and collective arguments presented here. We would like to thank the Journal of Colonialism and Colonial History for providing a forum for publishing the result of these discussions, and express our special gratitude to the journal's editor Clare Anderson and editorial assistant Emma Battell Lowman for supporting us throughout the process of publication.

\section{Notes}


${ }^{1}$ Andrew Thompson and Gary B. Magee, Empire and Globalisation: Networks of people, goods and capital in the British World, c. 1850-1914 (Cambridge: Cambridge University Press, 2010).

${ }^{2}$ Lauren Benton, "Introduction: Forum on Law and Empire in Global Perspective," The American Historical Review 117(4) (2012): 1092-1100.

${ }^{3}$ Legal pluralism used to be studied as the presence of multiple laws, including certain parts of indigenous laws, formally recognised within an overarching legal system, usually that of a colonial or imperial state. As the discussion below will show, the working definition of this phenomenon has greatly evolved. For a useful introduction, see Sally Engle Merry, “Legal Pluralism,” Law and Society Review 22/5 (1988): 869896

${ }^{4}$ Lauren Benton, Law and Colonial Cultures: Legal regimes in world history, 14001900 (Cambridge: Cambridge University Press, 2002); Benton, A Search for Sovereignty: Law and geography in European empires, 1400-1900 (Cambridge: Cambridge University Press, 2010); Eliga Gould, “Entangled Histories, Entangled Worlds: The English-speaking Atlantic as a Spanish periphery,” AHR Forum “Entangled Empires,” American Historical Review 112/3 (2007): 764-786.

5 The term "lawfare," implying the coercive, controlling functions of colonial law was used in John L. Comaroff, "Colonialism, Culture, and the Law: A foreword," Law and Social Inquiry 26/ 2 (2006): 305-314.

${ }^{6}$ Lauren Benton, "Colonial Law and Cultural Difference: Jurisdictional politics and the formation of the colonial state," Comparative Studies in Society and History 41/3 (1999): 563-588; Benton, A Search for Sovereignty; Benton, Law and Colonial Cultures.

${ }^{7}$ An excellent example being Eliga Gould, "Entangled Histories."

${ }^{8}$ Although not about law and empire as such, Isabel Hofmeyr's survey of the emerging themes and connections in Indian Ocean historiography point to many works (on trade, migration, labour and race for example) which have significant legal aspects, and whose authors have written elsewhere on specifically on legal themes. Isabel Hofmeyr, "The Black Atlantic meets the Indian Ocean: Forging new paradigms of transnationalism for the Global South-literary and cultural perspectives," Social Dynamics: a Journal of African Studies 33(2) (2007): 3-32. 
9 Sunil Amrith, “Indians Overseas? Governing Tamil Migration to Malaya, 18701941," Past and Present 208 (2010): 231-61; Sarah Abrevaya Stein, "Protected Persons? The Baghdadi Jewish diaspora, the British state, and the persistence of empire," American Historical Review 116 (1) (2011): 80-108; Marilyn Lake and Henry Reynolds, Drawing the Global Colour Line: White men's countries and the international challenge of racial equality (Cambridge: Cambridge University Press, 2008); Michael Fisher, "Excluding and Including 'Natives of India': Early-nineteenthcentury British-Indian race relations in Britain," Comparative Studies of South Asia, Africa and the Middle East 27/2 (2007): 303-314.

${ }^{10}$ Such as Sameeta Agha and Elizabeth Kolsky, eds., Fringes of Empire: People, places and spaces in colonial India (New Delhi: Oxford University Press, 2009). ${ }^{11}$ Clare Anderson, Subaltern Lives: Biographies of colonialism in the Indian Ocean world, 1790-1820 (Cambridge: Cambridge University Press, 2012), which develops on her earlier work in Convicts in the Indian Ocean: Transportation from South Asia to Mauritius, 1815-53 (Basingstoke: Macmillan, 2000) and The Indian Uprising of 1857-8: Prisons, prisoners, and rebellion (London: Anthem Press, 2007). The latter book was especially effective in exploring the maritime and multi-sited nature of an event that has always been studied as land-based and territorially bounded.

${ }^{12}$ Simon Layton, "Discourses of Piracy in an Age of Revolutions," Itinerario 35/2 (2011): 81-97.

${ }^{13}$ Surveyed in Zoe Laidlaw, "Breaking Britannia's Bounds? Law, settlers and space in Britain's imperial historiography," Historical Journal 55/3 (2012): 807-830.

${ }^{14}$ Mary Bilder, The Trans-Atlantic Constitution: Colonial legal culture and empire, (Cambridge, MA: Harvard University Press, 2004); Daniel Hulsebosch, Constituting Empire: New York and the transformation of constitutionalism in the Atlantic World, 1664-1830 (Chapel Hill: University of North Carolina Press, 2005); and also his "The Ancient Constitution and the Expanding Empire: Sir Edward Coke's British jurisprudence," Law and History Review 21.3 (2003): 439-482; Bernard Bailyn, Ideological Origins of the American Revolution (Cambridge: Harvard University Press, 1992); Jack P. Greene, Peripheries and Center: Constitutional development in the extended polities of the British Empire and the United States, 1607-1788 (New York and London: W.W. Norton Publishing, 1990). 
15 Anthony Pagden, "Human Rights, Natural Rights, and Europe's Imperial Legacy," Political Theory 31/2 (April 2003): 171-199; Eliga Gould, “Zones of Law, Zones of Violence: The legal geography of the British Atlantic, circa 1772," William and Mary Quarterly 60/3 (2003): 471-510.

${ }^{16}$ Eliga Gould, Among the Powers of the Earth: The American Revolution and the making of a new world empire (Cambridge, MA: Harvard University Press, 2012).

${ }^{17}$ To refer to Partha Chatterjee's oft-cited formulation, in The Nation and its Fragments: Colonial and postcolonial histories (Princeton: Princeton University Press, 1993).

${ }^{18}$ Thomas Carlyle, Chartism (1839), cited in Diana C. Archibald, Domesticity, Imperialism and Emigration in the Victorian Novel (Missouri: University of Missouri Press, 2002): 37-39.

${ }^{19}$ Peter Fitzpatrick, The Mythology of Modern Law (London, New York: Routledge, 1992); Giorgio Agamben, State of Exception, trans. Kevin Attell (Chicago, London: University of Chicago Press, 2005).

${ }^{20}$ Bernard Cohn, "Law and the Colonial State," in Colonialism and its Forms of Knowledge, Bernard Cohn (Princeton: Princeton University Press, 1996), 57-75;

Cohn, "Some Notes on Law and Change in North India," Economic Development and Cultural Change 8:1 (1959): 79-93; Cohn, "From Indian Status to British Contract," Journal of Economic History 21 (1961); also suggested by David Washbrook, "Law, State and Agrarian Society in Colonial India," Modern Asian Studies 15: 3(1981): 649-721

${ }^{21}$ Robin Law, Ouidah: The social history of a West African slaving “port," 17271892 (Oxford: James Currey, 2004).

${ }^{22}$ David Washbrook, "Law, State, and Agrarian Society," 653.

${ }^{23}$ Radhika Singha, A Despotism of Law: Crime and justice in early Colonial India (New Delhi: Oxford University Press, 1998).

${ }^{24}$ Jennifer Pitts, A Turn to Empire: The rise of imperial liberalism in Britain and France (Princeton: Princeton University Press, 2005).

${ }^{25}$ Robert Travers, Empire and Ideology in Eighteenth-Century India: The British in Bengal (Cambridge: Cambridge University Press, 2007). 
${ }^{26}$ Martin Chanock, The Making of South African Legal Culture, 1902-1936: Fear, favour and prejudice (Cambridge, Cambridge University Press, 1987), especially 243357; also Peter Fitzpatrick, "Traditionalism and Traditional Law," Journal of African Law 28, no. 1/2 (1984): 20-27.

${ }^{27}$ Sally Falk Moore, Social Facts and Fabrications: "Customary law" on Kilimanjaro, 1880-1980 (Cambridge: Cambridge University Press, 1986).

${ }^{28}$ Partha Chatterjee, The Nation and its Fragments.

${ }^{29}$ Lata Mani, Contentious Traditions: The debate on sati in colonial India (Berkeley: University of California Press, 1998); Patricia Stamp, "Burying Otieno: The politics of gender and ethnicity in Kenya," Signs 16: 4 (1991): 808-845.

${ }^{30}$ Eliga Gould, "Dependence, Independence, and Interdependence: The law of nations and representations of the national self in the Greater British World, 1776 to 1826" (keynote address at the conference "Poetics of Law, Politics of Self," Mount Edgcumbe (UK), 6 September 2013); Robert J. Miller, “Tribal Constitutions and Native Sovereignty," (4 April, 2011), available at SSRN:

http://ssrn.com/abstract=1802890 or http://dx.doi.org/10.2139/ssrn.1802890.

${ }^{31}$ For example, several essays in Kristin Mann and Richard Roberts, eds., Law in Colonial Africa (London: James Currey, 1991), but especially David Groff, “The Dynamics of Collaboration and the Rule of Law in French West Africa: The case of Kwame Kangah of Assikasso (Côte d'Ivoire), 1898-1922” in Kristin Mann and Richard Roberts, eds., Law in Colonial Africa (London: James Currey, 1991), 146166.

${ }^{32}$ Richard White, The Middle Ground: Indians, empires, and republics in the Great Lakes Region, 1650-1815 (Cambridge: Cambridge University Press, 2011 [1991]).

${ }^{33}$ Mattison Mines, "Courts of Law and Styles of Self in Eighteenth-Century Madras: From hybrid to colonial self," Modern Asian Studies 35:1 (2001): 33-74; Neil Brimmes, "Beyond Colonial Law: Indigenous litigation and the contestation of property in the Mayor's Court in late-eighteenth century Madras," Modern Asian Studies 37/3 (2003): 513-550.

${ }^{34}$ Anderson, Subaltern Lives.

${ }^{35}$ Peter Marshall, The Making and Unmaking of Empires: India, Britain and America, c. 1750-1783 (Oxford: Oxford University Press, 2005). 